\title{
Genetic Variability, Heritability and Genetic Advance Studies in Gloriosa superba Linn.
}

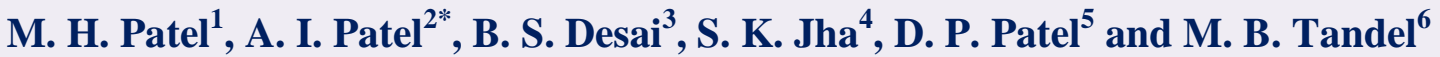

${ }^{1}$ Department of Forests Products and Utilization, ${ }^{2}$ Plant Breeding and Genetics, Department of Vegetable Sciences, ${ }^{3}$ Department of Basic Sciences \& Humanities, ${ }^{4}$ Department of Forest Biology \& Tree Improvement, ${ }^{5}$ Soil Sciences, Department of Natural Resources Management, ${ }^{6}$ Forestry Department of Silviculture \& Agroforestry, College of Forestry, ASPEE College of Horticulture and Forestry, Navsari Agricultural University, Navsari-396450, Gujarat, India

*Corresponding author

\section{A B S T R A C T}

\section{Keywords}

Gloriosa superba,

Heritability,

Genetic advance,

Variability,

Colchicine

\section{Article Info}

Accepted:

26 January 2021

Available Online:

10 February 2021
An effort was made to assess the variability using parameters like PCV, GCV, heritability, genetic advance in Gloriosa superba Linn. Observations were recorded on nineteen characters showing considerable variability. PCV was higher than the respective GCV for all the traits. The high magnitude of PCV and GCV was observed for plant height, collar diameter, number of flowers per plant, number of fruits per plant, number of seeds per plant, dry weight of fruit, number of tubers per plant, tuber length, tuber fresh weight, tuber dry weight and Colchicine content. High heritability coupled with high genetic advance was observed for most of the characters except leaf area, intermodal length, fruit length and fresh weight of fruit. It indicated that additive gene action was more important for these characters.

\section{Introduction}

Gloriosa superba Linn., is one of the medicinal plant cultivated as a commercial crop and it gives more economic returns. In India it is cultivated in Erode, Salem, Tirupur, Dindugal and Karur districts of Tamil Nadu. In Gujarat and South Gujarat, Pipargota, Kanjeta and Chari in Ratanmahal WLS, Bansda, Waghai, Purna WLS and Saputara in
Dangs, Ambatala in Dharampur forests, Mathavali and Sagai in Shoolpaneshwar WLS. Scattered in parts of Saurashtra (Shah, 1978). The yield of Gloriosa superba Linn. depending on age of the plant, treatment, soil and vigour the yield of seeds and tubers vary. The generic name Gloriosa means 'full of glory' and superb means 'superb', alluding to the striking red and yellow flowers. It is a native species of Tropical and Southern 
Africa to Asia and has naturalized-in Australia and the Pacific and is being widely cultivated. The most common English names are Flame lily, Fire lily, Gloriosa lily, Glory lily, Superb lily, Climbing lily and Creeping lily. They are tender, tuberous rooted deciduous perennials, adapted to summer rainfall with a dormant dry season.

Gloriosa contain colchicine, the roots and seeds are especially rich. Tubers and seeds contain colchicine, isoperlolyrine and related tropolane alkaloids, sitosterol and its glucoside, 2-hydroxy 6- methoxy benzoic acid. Flowers contain Luteolin, its Glucoside, NFormyl- de-Me-colchicine, its Glucoside and 2-de-Me-colchicine.

Gloriosa superba Linn. is used in wounds, skin related problems, fever, inflammation, piles, blood disorders, uterine contractions, general body toner, poisoning etc. The flower has analgesic, anti -inflammatory, antimicrobial, antiviral, antithrombotic, antitumor and also used in treatment of snake bite, skin diseases, respiratory disorders etc. The tuber is used for the treatment of bruises and sprains, chronic ulcers, cancer, impotence, nocturnal seminal emission, and in care of leprosy, anthelmintic, antipyretic, bitter, digestive, expectorant, highly poisonous and abortifacient. Tuber paste is effective against paralysis, rheumatism, snake bite and insect bite (Senthilkumar, 2013).

Creation and utilization of variability using proper breeding procedure is a pre-requisite for the genetic improvement of any crop. Generally, amount of variability is more in the early segregating generations as compared to later generations. The phenotypic expression of the plant character is mainly controlled by the genetic makeup of the plant and the environment in which it is growing. Therefore, it becomes necessary to partition the observed phenotypic variability into its heritable components with suitable parameters such as phenotypic and genotypic coefficient of variation, heritability and genetic advance as per cent of mean.

\section{Materials and Methods}

The present research work was carried out at the Model Nursery on Medicinal and Aromatic Plants, ASPEE College of Horticulture and Forestry, NAU, Navsari, Gujarat from July 2016 to July 2017. Initially 20 accessions were selected and marked with GPS from different locations of South Gujarat region for variability study. The accessions were selected and collected from Valsad, Navsari and Surat districts of South Gujarat region. The tubers were planted in pots consisting of Sand: Soil: FYM (1:1:1). After four months, observations were recorded for various parameters. The GCV and PCV were determined according to Burton and Devane (1953). Heritability in broad sense was calculated using formula proposed by Allard (1960) and expressed in percentage. Genetic advance for each character was predicted by the formula given by Johnson et al., (1955). Mean values were used to determine characters' variances, coefficients of variation, broad sense heritability and genetic advance percentage of mean.

\section{Results and Discussion}

The possibility of achieving improvement in any crop plants primarily depends on the magnitude of genetic variability. Though heritability value of a trait indicates the effectiveness of selection based on phenotypic expression, though selection is the product of its heritability, phenotypic standard deviation and selection differential (Burton and Devane, 1953).

The genotypic variance followed the trend of phenotypic variance and was greater than 
environmental variance for all the characters. This implied that phenotypic variability might be considered as a reliable measure of genotypic variability. In the present study, the phenotypic and genotypic variances were greater than the environmental variance for all the character under study which indicated that influence of environment on expression of traits was lower or negligible, hence selection would be effective (Table 1).

With view to compare different quantitative characters in respect of phenotypic and genotypic variability, phenotypic coefficient of variation and genotypic coefficient of variation were calculated. The genotypic coefficient of variation measures the range of inherent variation present in a character and helps to compare the variability present in different characters. The PCV and GCV measure the extent of variation present in the population in the particular character.In the present investigation, PCV was higher than the respective GCV for all the traits (Table 1), denoting the environmental factors influencing their expression to some degree. For the improvement of species, genetic component of variation is the only important factor to be transmitted to next generation. Similar results were reported by Kumar et al., (1979), Ram and Singh (1993) and Selvarasu and Kandhasamy (2017).

The high magnitude of PCV and GCV was observed for colchicine content followed by tuber dry weight, tuber fresh weight, number of flowers per plant, number of fruits per plant, number of seeds per plant, number of tubers per plant, collar diameter, tuber length and dry weight of fruit. This high magnitude of PCV and GCV for above characters suggested greater phenotypic and genotypic variability among the different genotypes indicated that these characters can be improved through phenotypic selection. Similar results were reported by Kumar et al.,
(1979), Ram and Singh (1993) and Selvarasu and Kandhasamy (2017).

However, low magnitudes of GCV and PCV were recorded for leaf area, internodal length, and fresh weight of fruit, among which the leaf area has the lowest GCV and PCV. The most probable reason could be the phenotypic plasticity occurring in these traits is the main source of variation than the genetic variance. Such result also indicated that selection is not effective for these traits because of the narrow genetic base (Vishwas, 2019).

Heritability in broader sense may also give useful indication about the relative values for selection of material in hand, but to arrive at more reliable conclusion, heritability should be considered with genetic relevance. The heritability estimate provide the information on the magnitude of inheritance of quantitative characters but does not indicate the magnitude of genetic gain obtained by selection of best individual from the best population. So, heritability along with genetic advance is more useful than the heritability alone.

In this experiment, heritability and genetic advance is higher for all the characters except leaf area, intermodal length and fresh weight of fruit. In present study, high genetic advance coupled with high heritability was observed for most of the characters. It indicated that additive gene action was more important for these characters. Similar results were reported by Chitra and Kandhsamy (2009) and Selvarasu and Kandhasamy (2017).

The low heritability coupled with low genetic advance was recorded for leaf area, internodal length, and fresh weight of fruit indicating high influence of environment and consequently its selection may not be effective. 
Table.1 GCV \%, PCV \%, heritability $\left(\mathrm{h}^{2} \mathrm{bs} \%\right)$ and genetic advance as per cent of mean (GAM \%) for various traits

\begin{tabular}{|c|c|c|c|c|c|}
\hline Characters & GCV & ECV & PCV & $\mathbf{H}^{2}(\%)$ & GA \\
\hline Plant height (m) & 18.40 & 1.96 & 31.74 & 66.0 & 30.89 \\
\hline Collar diameter (mm) & 22.92 & 2.79 & 40.24 & 68.0 & 38.81 \\
\hline Leaf area $\left(\mathrm{cm}^{2}\right)$ & 8.15 & 55.21 & 9.09 & 20.0 & 7.44 \\
\hline Inter nodal length(cm) & 8.82 & 3.76 & 10.41 & 28.0 & 9.66 \\
\hline Fresh weight of plant (g) & 19.14 & 48.35 & 40.05 & 77.0 & 34.64 \\
\hline Dry weight of plant(g) & 18.83 & 38.91 & 32.84 & 67.0 & 31.78 \\
\hline Number of flowers/plant & 50.54 & 2.34 & 240.59 & 96.0 & 101.78 \\
\hline Number of fruits/plant & 41.71 & 3.02 & 108.76 & 85.0 & 79.35 \\
\hline Number of seeds/plant & 37.00 & 7.16 & 81.15 & 79.0 & 67.83 \\
\hline Fruit length(cm) & 15.00 & 4.76 & 20.97 & 49.0 & 21.59 \\
\hline Fruit width (mm) & 16.03 & 8.80 & 29.29 & 70.0 & 27.64 \\
\hline fresh weight of fruit(g) & 8.35 & 8.21 & 9.80 & 27.0 & 8.99 \\
\hline dry weight of fruit (g) & 21.27 & 1.69 & 37.93 & 69.0 & 36.28 \\
\hline Number of tubers/plant & 34.61 & 0.50 & 88.62 & 85.0 & 65.64 \\
\hline Tuber length $(\mathrm{cm})$ & 21.85 & 8.45 & 50.63 & 81.0 & 40.60 \\
\hline Tuber width (mm) & 15.43 & 9.89 & 26.17 & 65.0 & 25.68 \\
\hline Tuber fresh weight (g) & 64.69 & 9.25 & 367.57 & 97.0 & 131.17 \\
\hline Tuber dry weight (g) & 74.81 & 3.39 & 521.91 & 98.0 & 152.52 \\
\hline Colchicine content (mg/g) & 101.42 & 16.83 & 102.81 & 97.0 & 206.12 \\
\hline
\end{tabular}

In the present study, the difference between PCV and GCV were higher for most of the characters except leaf area, inter nodal length and fresh weight of fruit which suggesting higher role of environment in the expression of traits, so improvement in these traits is not easily possible by phenotypic selection. The present results indicated that high heritability coupled with high genetic advance were recorded for majority of the traits indicating the role of additive gene action in the inheritance of these traits, hence further improvement in these characters would be achieved by selection in the present material.

\section{References}

Allard, R. W. (1960). Principles of Plant breeding, 04: SB123, A5.

Burton GW, Devane EH. Estimating heritability in tall Fescue (Festuca arundinacea) from replicated clonal 
material. J. Agron. 1953; 45:478-481.

Chitra R. and Kandhasamy, R. (2009). Genetic variability, heritability and scope of improvement for yield components in glory lity (Gloriosa superba L.). International Journal of Plant Breeding, 3(2); 139-143.

Johnson, H. W., Robinson, H. R. and Comstock, R. E. (1955). Estimation of genetic and environmental variability in soybean (Glycine $\max$ L.). Agron. J., 47: 314-318.

Kumar, N., Muthukrishnan, C.R. and Irullapan, I. (1979). Correlation and path analysis in segregating generations of Tomato. South Indian Hort., 27: $33-$ 49.

Ram, G. and Singh, S. (1993). Genetic analysis of yield and its components in urdbean (Vigna mungo (L.) Hepper.).
Indian Journal of Pulses Research, 6:194-196.

Selvarasu, A. and Kandhasamy, R. (2017). Molecular and Agro-morphological genetic diversity assessment of Glorisa superba Mutants. European Journal of Medicinal Plants, 21(1);1-13.

Senthilkumar, M. (2013). Phytochemical Screening of Gloriosa superba Linn. from different Geographical Positions. Int. J. Sci. and Res., 3 (1): 1-5.

Shah, G. L. (1978). Flora of Gujarat. Vol. II. Published by Registrar, Sardar Patel University, Gujarat.

Vishwas (2019). Genetic diversity, character association and path coefficient analysis in coriander (Coriandrum sativum L.). M. Sc. (GPB) thesis, Navsari Agricultural University, Navsari. Gujarat.

\section{How to cite this article:}

Patel, M. H., A. I. Patel, B. S. Desai, S. K. Jha, D. P. Patel and Tandel, M. B. 2021. Genetic Variability, Heritability and Genetic Advance Studies in Gloriosa superba Linn. Int.J.Curr.Microbiol.App.Sci. 10(02): 3278-3282. doi: https://doi.org/10.20546/ijcmas.2021.1002.360 